\author{
Olena Milienko ${ }^{1}$
}

\title{
ADMINISTRATIVE AGREEMENT AS A COMPONENT OF THE SYSTEM OF PUBLIC GOVERNANCE TOOLS
}

Keywords: administrative procedure, act-plan, act-actions, public administration tool, public contract, public administration.

\begin{abstract}
The purpose of the article is to implement the characteristics of the administrative contract as a component of the system of public administration tools. It is determined that the system of tools for the implementation of functions by public administration bodies must meet the requirements of efficiency of settlement of management tasks, mobility of implementation of management decisions, accessibility of administrative procedures, and openness of regulations and administrative acts. The system of tools of public administration includes decisions, actions or omissions of public authorities and local governments, which have fundamental legal significance and consequences for individuals. It is emphasized that the implementation of the concept of «good governance» must comply with the democratic principles of building the rule of law, the achievement of which requires the use of the system of tools defined by current legislation. The components of the system of public administration tools include bylaws (actually identifying them with regulations), administrative acts, administrative agreements, administrative acts and acts-plans. The normative-legal character of the administrative agreement is determined, which to some extent identifies it with the normative acts of the subjects of power, emphasizing the bilateral and multilateral nature of such relations. It is substantiated that administrative contracts have similar features that are similar to other instruments of public administration, in particular, the need to conclude them in accordance with the established procedure, aimed at satisfying subjective public rights, and so on. It is established that the distinctive features of an administrative agreement are its voluntary nature of adoption, bilateral
\end{abstract}

1 Candidate of Law, Postdoctoral Student at the Department of Administrative and Commercial Law, Zaporizhia National University, mariyahorishnya@gmail.com. ORCID: 0000-0002-3364-1774. 
and multilateral nature of the regulation of public relations, and one of the parties to the agreement is always the subject of power. It is concluded that in the implementation of administrative-contractual relations there is a situation of legal equality of its parties, so the mechanism for ensuring its implementation is specific. It is concluded that an administrative agreement is a public accession agreement, the content of which is the implementation of management functions related to the provision of public services, ensuring the efficient use of public property between the subject of power at the initiative of a non-governmental entity. It is substantiated that in the current conditions in order to ensure the availability of legislation, as well as to avoid the situation of emergency accumulation of an array of regulations, it is proposed to supplement the draft Law of Ukraine «On Administrative Procedure» with the following provisions: «administrative contract implementation of management functions related to the provision of public services, ensuring the efficient use of public property, concluded between the subject of power at the initiative of a non-governmental entity.

\section{INTRODUCTION}

The main task of the system of public administration is to ensure the subjective public and private rights of the individual. Implementation of the tasks of the system of public administration bodies is a component of domestic and foreign state policy. Priority is given to ensuring regulatory regulation of the implementation of tasks of external and internal functions of public administration. Achieving the appropriate level of legal efficiency of the functioning of public administration requires the introduction of a flexible system of forms of their activities (tools of public administration) (Paterilo, 2014, p. 175).

\section{THE STATE OF SCIENTIFIC DEVELOPMENT OF THE PROBLEM}

Ongoing activities to improve the current administrative and procedural legislation results in a controversial understanding of the category of «administrative contract».In general, the study of the system of tools of public administration was carried out in the scientific works of IV Paterylo, VP Tymoschuk, AM Shkolyk, SP Rabinovych and others. 
This conclusion, in our opinion, further actualizes the current need for additional research on the institute of administrative act in Ukrainian administrative law. And here we inevitably face the need to draw a certain theoretical and methodological framework around which to build our own conceptual model of administrative act as an institution of administrative law, in particular the establishment of the feasibility of using a dialectical method of scientific knowledge in determining the essence of the category.

The purpose of the scientific article. The purpose of the article is to implement the characteristics of the administrative contract as a component of the system of public administration tools.

\section{CHARACTERISTICS OF THE SYSTEM OF PUBLIC ADMINISTRATION TOOLS}

The system of tools for the performance of functions by public administration bodies must meet the requirements of efficiency of management tasks, mobility of management decisions, accessibility of administrative procedures, and open adoption of regulations and administrative acts (Melnyk, 2010, pp. 165-166).

An administrative act belongs to the system of instruments of activity of subjects of public administration, provided that its action is directed at specific subjects of administrative law, which reveals its individual nature of regulatory regulation.

The category «tool of public administration» is a relatively new category for modern science of administrative law and process, introduced, in particular, in the research of RS Melnik (Melnik, 2010, pp. 166-170). In this case, the components of the subsystem of legal acts by scientists is a set of regulations and administrative acts adopted by public administration.

I.B. Pateril emphasizes that the system of tools of public administration includes primarily manifestations of the functioning of government powers that have an external influence on individuals - individuals and legal entities of private law. I.B. Paterilo uses a very unusual approach, noting 
that public administration tools have a «dangerous» impact on the individual (Paterilo, 2014, p. 176). «Danger», according to the scientist is manifested in the likelihood of negative harmful restrictive consequences for the individual (Paterilo, 2014, pp. 176-177).

In general, supporting the innovative ideas of IV Paterilo, I would like to note that the direction of public service activities with its unconditional priority is to achieve a balance of private and public interest (Zolotukhina, 2019, pp. 61-64; Legeza, 2018, pp. 233-235; Kuntsevich, 2014, pp. 11-15), providing constitutional human rights and freedoms, which in any case can not be described as a manifestation of «danger» of regulation, so the use of such a characteristic of public administration tools, we consider premature and inconsistent with the concept of «good governance».

The European Commission for Democracy through Law (Venice Commission) includes elements of good governance and accountability of public authorities; compliance with transparency requirements; the need to respond to people's needs; productivity of management decisions and the effectiveness of their implementation, which should be ensured by public involvement, access to public information, as well as taking into account legitimate expectations as part of the system of constitutional rights and freedoms of the individual. This European Strategy for Innovation and Good Governance at the local level enshrines such principles of public administration as: 1) fair elections, representation and participation, in order to provide real opportunities for all citizens to have a voice in local affairs; 2) sensitivity to ensure an appropriate response of local authorities to the legitimate expectations and needs of citizens; 3 ) efficiency and effectiveness to ensure the achievement of goals and at the same time the most rational use of resources; 4 ) openness and transparency to ensure public access to information and to facilitate understanding of public affairs; 5) the rule of law to ensure justice and political neutrality of local authorities in their activities; 6) ethical behavior to ensure the predominance of public interests over private ones; 7) competence and capacity to ensure the ability of representatives and officials of local authorities to perform their duties; 8) innovation and openness to change to ensure that new solutions and best practices benefit; 9) sustainable development and focus on long-term results to take into account the 
interests of future generations in preserving the national (local) heritage; 10) sound financial management to ensure economical and productive use of public finances and other material resources; 11) human rights, cultural diversity and social cohesion to ensure the protection and respect of all citizens; 12) accountability to ensure the accountability of local government officials for their actions (The Council of Europe Strategy on Innovation and Good Governance at Local Level, 2007).

Thus, the implementation of the concept of «good governance» must comply with the democratic principles of building the rule of law, which requires the use of a system of tools defined by current legislation. I.B. Paterilo also includes bylaws (actually identifying them with normative ones), administrative acts, administrative agreements, administrative actsactions and acts-plans as components of the system of public administration tools (Paterilo, 2014, p. 177).

In general, the intermediate conclusion about the existence of unity of scientific and theoretical approaches to understanding the essence of the system of tools of public administration (administration), the components of which include regulations, administrative acts, administrative agreements, administrative acts and acts-plans.

\section{CHARACTERISTICS OF THE ADMINISTRATIVE CONTRACT AS A TOOL OF PUBLIC ADMINISTRATION}

The components of public administration tools include administrative agreements. It should be noted that despite the proclamation of strategic objectives for the development of contractual principles of relations between individuals and public authorities in accordance with the provisions of the Concept of Administrative Reform of 1998, as well as the provisions of the Code of Administrative Procedure of Ukraine in 2005. relations administrative agreements, the real possibility of their introduction took place with the adoption of the Law of Ukraine «On Amendments to the Commercial Procedural Code of Ukraine, the Civil Procedure Code of Ukraine, the Code of Administrative Procedure of Ukraine and other legislation» from 03.10.2017. 
In accordance with the provisions of paragraph 16 of Part 1 of Art. 16 of the Criminal Procedure Code of Ukraine stipulates that the grounds for concluding administrative agreements are: the need to ensure the differentiation of competence or to determine the order of relations between public authorities and other subjects of power; redirection of part of public authority management functions; review of the movement of financial resources of local and state budgets; redistribution or pooling of budget funds in cases specified by law; is a replacement for an individual act; contributes to the optimization of the mechanism for providing administrative services.

A similar approach is substantiated in the scientific developments of S.S. Skvortsov, which notes such features of the administrative contract as voluntary nature, the subjective composition of legal relations (in particular, the participation of public administration) (Skvortsov, 2004, p. 109). One of the first noted the possibility of delegating discretionary powers in the administrative agreement KK Afanasyev (Afanasyev, 2004, p. 12), while scientists note the executive or administrative nature of such an instrument of power.

O.B. Constant emphasizes the normative-legal nature of the administrative agreement, thus to some extent identifying it with the normative acts of the subjects of power, but emphasizing the bilateral and multilateral nature of such relations. The administrative contract, as noted by the scientist, has an individual character, which is manifested in its ability to establish (change, terminate) specific legal relations between its participants (Constantine, 2005, p. 77). It is necessary to distinguish the approach substantiated by TO Kolomoyets, who notes the mixed nature of the administrative agreement, which consists in its ability as a normative regulation of relations by establishing mandatory rules of conduct and individual regulation by personification of public administration relations (Administrative Law of Ukraine, 2008, p. 105).

Thus, the administrative contract refers to the system of legal facts, ie the circumstances with the occurrence of which there is the emergence, change or termination of public administration relations. Administrative contracts have similar features that are similar to other instruments of public administration, in particular, the need to conclude them in accord- 
ance with the established procedure, aimed at satisfying subjective public rights, and so on. Distinctive features of an administrative agreement are its voluntary nature of adoption, bilateral and multilateral nature of the regulation of public relations, and one of the parties to the agreement is always the subject of power. Therefore, an intermediate conclusion is allowed that in the implementation of administrative-contractual relations there is a situation of legal equality of its parties, so the mechanism for ensuring its implementation is specific.

\section{CONCLUSIONS}

Taking into account the above considerations, it is necessary to determine that the administrative agreement is a public accession agreement, the content of which is the implementation of management functions related to the provision of public services, ensuring the efficient use of public property between the subject of government 'object.

In the current conditions, in order to ensure the availability of legislative regulation, as well as to avoid the situation of emergency accumulation of an array of regulations, it is proposed to supplement the draft Law of Ukraine «On Administrative Procedure» with the following provisions:

«An administrative agreement is a public accession agreement, the content of which is the implementation of management functions related to the provision of public services, ensuring the efficient use of public property, concluded between the subject of power at the initiative of a non-governmental entity».

\section{BIBLIOGRAPHY:}

Afanasiev, K.K. (2004). Admynystratyvni dohovory: realii y perspektyvy [Administrative agreements: realities and prospects]: Monohrafiia. Luhansk. RVV LAVS.

Halunko, V., Dikhtiievskyi, P., Kuzmenko, O., Stetsenko, S. (ed.) (2018). Administratyvne pravo Ukrainy. Povnyi kurs: pidruchnyk [Administrative law of Ukraine. Full course]. Kherson: OLDI-PLIuS. [in Ukrainian] 
Kolomoiets, T.O. (ed.) (2008). Administratyvne pravo Ukrainy [Administrative law of Ukraine]. Kyiv: «Istyna». [in Ukrainian]

Konstantyi, O.V. (2005). Dzherela administratyvnoho prava Ukrainy [Sources of administrative law of Ukraine]. Kyiv: Ukrainske ahentstvo informatsii ta druku «Rada». [in Ukrainian]

Kuntsevych, M.P. (2014). Publichni i pryvatni interesy yak tsinnosti, shcho okhoroniaiutsia administratyvnym pravom [Public and private interests as values protected by administrative law]. Pravovyi visnyk Ukrainskoi akademii bankivskoi spravy, vol. 2 (11), pp. 11-15.

Leheza, Yu. O. (2018). Administratyvno-pravovi zasady publichnoho upravlinnia u sferi vykorystannia pryrodnykh resursiv [Administrative and legal mechanism for ensuring the realization of public interest]. (PhD Thesis), Zaporizhzhia: ZNU.

Melnyk, R.S. (2010). Systema administratyvnoho prava Ukrainy [The system of administrative law of Ukraine]. Kharkiv: Vyd-vo Kharkiv. nats. un-tu vnutr. sprav. [in Ukrainian]

Paterylo, I.V. (2014). Instrumenty diialnosti subiektiv publichnoi administratsii: sutnist ta zmist. [Tools of activity of subjects of public administration: essence and maintenance]. Naukovyi visnyk Uzhhorodskoho natsionalnoho universytetu. Seriia Pravo. no. 27. vol. 2. pp. 174-178.

Skvortsov, S.S. (2004). Poniatye y yurydycheskoe znachenye admynystratyvnoho dohovora $\mathrm{v}$ upravlenchyskoi deiatelnosty hosudarstva [The concept and legal significance of an administrative contract in the management activities of the state]. Vestnyk Odesskoho ynstytuta vnutrennykh del, no. 2, pp. 105-109.

Stocktaking on the notions of «Good Governance» and «Good Administration»: European Commission for Democracy through Law (Venice Commission); Strasbourg, 8 April 2011, Study no. 470 / 2008, CDL-AD(2011)009. Retrieved from: http://www. venice.coe.int/docs/2011/CDL-AD\%282011\%29009-e.pdf.

The Council of Europe Strategy on Innovation and Good Governance at Local Level, MCL-15(2007)8, adopted on 16 October 2007. Retrieved from: https://wcd.coe.int/ com.instranet.InstraServlet?command=com.instranet.CmdBlobGet\&InstranetImag $\mathrm{e}=1095949 \&$ SecMode $=1 \&$ DocId $=1350476 \&$ Usage $=2$.

Zolotukhina, L.O. (2019). Administratyvno-pravovyi mekhanizm zabezpechennia realizatsii publichnoho interesu [Administrative and legal mechanism for ensuring the realization of public interest]. Jurnalul juridic national: teorie şi practică, no. 4 (38), pp. 61-64. 